\title{
2,2'-Bipyridyl Chelated Ru(II)-Annulated NHC Complex of 1- Methyl-2-Pyridin-2-Yl-2H-Imidazo[1,5-a]Pyridin-4-Ylidene: Synthesis, Structure, Optical Properties, and DFT Interpretation
}

Bidyut Kumar Rana,,${ }^{1,3, ¥, *}$ Joydev Dinda, ${ }^{2,}{ }^{*}$ Pradip Kumar Mahapatra, ${ }^{3}$ Deepak Chopra, ${ }^{4}$ Valerio Bertolasi, ${ }^{5}$ Keshab M. Bairagi, ${ }^{6}$ Susanta K. Nayak, ${ }^{6}$ Himadri Sekhar Das, ${ }^{1}$ Santanab Giri ${ }^{1}$ and Gourisankar Roymahapatra ${ }^{1}$

\begin{abstract}
This article depicts the synthesis of $\mathrm{Ru}(\mathrm{II})-\mathrm{NHC}$ complex, $\left[\mathrm{Ru}(\mathrm{bpyy})(\mathrm{NHC})\left(\mathrm{CH}_{3} \mathrm{CN}\right)_{2}\right]\left[\mathrm{PF}_{6}\right]_{2}$ (2); $[\mathrm{NHC}=1$-methyl-2(pyridyl)imidazo[1,5-a]pyridine-2-yiledene, bpy $=2,2$ '-bipyridine] via $\mathrm{Ag}(\mathrm{I})$-carbene trans-metallation process. X-ray diffraction studies of compound 2 elucidate the triclinic crystal system of a single crystal with a distorted octahedral geometry. To insight into the structure and optoelectronic properties, density functional theory (DFT) and time-dependent density functional theory (TDDFT) studies were performed, and the absorption spectra were of intra-ligand charge transfer transitions (ILCT) character along with the large contribution of (metal-ligand charge transfer (MLCT) transition in complexes. Compound 2 is fluorescent active and it is expected that the source of fluorescence is due to the presence of 2,2'-bipyridine fluorophore. Hirshfeld model studies were also performed of the crystal structure to illustrate the nature of intermolecular interactions present in the structure in the crystalline environment, and the molecule possesses several $\mathrm{C}-\mathrm{H}$.... $\mathrm{F}^{-}$weak $\mathrm{H}$-bonding interactions. The molecule paves the way toward a new pro-apoptotic and antimicrobial compound against various cancer cells and is also a useful pre-catalyst for different types of hydrogenation reactions.
\end{abstract}

Keywords: Ru(II)-NHC complex, Optical Properties, DFT, TDDFT, Hirshfeld.

Received: 03 November 2021; Revised: 08 January 2022; Accepted: 13 December 2021.

Article type: Research article.

\section{Introduction}

$\mathrm{Ru}(\mathrm{II})$-complexes bearing polypyridine systems are still the area of intensive research ${ }^{[1-8]}$ due to their photophysical properties. In the last three decades, attention has been given to intense applications starting from optoelectronic devices to targeted drug design. Ruthenium bipyridine complexes such as $\left[\mathrm{Ru}(\mathrm{bpy})_{3}\right]^{2+}$ and its derivatives (Chart 1) have been extensively studied as active components in a variety of applications including supramolecular assembly,

${ }^{1}$ School of Applied Science and Humanities, Haldia Institute of Technology, Haldia 721657, India.

2 Department of Chemistry, Utkal University, Bhubaneswar 751004, Odisha, India.

${ }^{3}$ Department of Chemistry, Jadavpur University, Kolkata 700032, India.

${ }^{4}$ Department of Chemistry, Indian Institute of Science Education and Research Bhopal, Bhauri, Bhopal 462 066, Madhya Pradesh, India.

5 Dipartimento di Chimica and Centro di Strutturistica Diffrattometrica, Universita' di Ferrara, Via L. Borsari, 46, Italy. photoinduced electron-transfer reactions, and photochemistry. Several model complexes have been synthesized and compared with the most widely studied, $\left[\mathrm{Ru}(\mathrm{bpy})_{3}\right]^{2+}(\mathrm{bpy}=$ 2,2'-bipyridine), an ideal photosensitizer. ${ }^{[9,10]}$ This class of compounds shows excellent properties such as photosensitizers in dye-sensitized solar cells (DSSCs) and has thus been pivotal for advancing light-to-energy conversion technology. ${ }^{[11,12]}$ Tremendous modifications in the polypyridine substitution pattern have been successfully applied for improving the metal-centered redox and excitedstate properties. ${ }^{[13-17]}$ Many groups have contributed to the improvement of the photophysical properties of such complexes, either by lowering the energy of the triplet metalligand charge transfer transitions (MLCT) excited state or by increasing the $\mathrm{MC}$ state energy, the common objective being to place the two states as far as possible from one another. ${ }^{[18-23]}$

Replacement of one or several pyridine ligand sites by Nheterocyclic carbenes (NHCs) has received surprisingly little attention. ${ }^{[24-27]}$ To gain an insight into the photochemical reactions of carbene complexes, it is necessary to characterize the lowest-lying electronic excited states and their 
photophysical deactivation mechanisms. After the first successful isolation of N-heterocyclic carbene (NHC) by Arduengo et al. ${ }^{[28]}$ in 1991, there has been immense growth in the field of chemical, ${ }^{[14,29-31]}$ structural, ${ }^{[32-35]}$ biomedical ${ }^{[36-39]}$ and photophysical properties. ${ }^{[40-42]} \mathrm{NHCs}$ can form strong bonds with a broad spectrum of transition metals in various oxidation states and often afford stable complexes. ${ }^{[43-45]}$ Efforts have been directed toward the development of novel NHC scaffolds. In this work, efforts are directed toward the synthesis, characterization, photophysical, DFT, TDDFT, and Hirshfeld model studies of bpy chelated Ru (II) complex supported by a known NHC, 1-methyl-2-pyridin-2-yl-2H-imidazo[1,5a]pyridine-4-ylidene (1). ${ }^{[46]}$
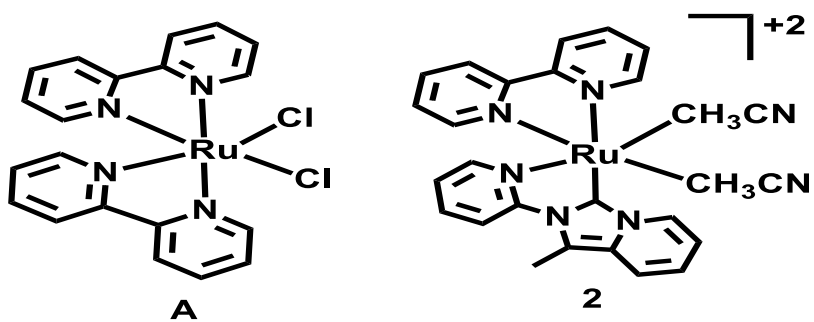

Chart 1. $\left.\mathrm{Ru}(\mathrm{bpy})_{2}\right] \mathrm{Cl}_{2}$ complex A and studied complex 2 .

\section{Experimental Section}

\subsection{General procedures}

All the reagents (e.g. 2-acetylpyridine, 2-aminopyridine, $\mathrm{Ag}_{2} \mathrm{O}$, $\left[\mathrm{Ru}(p \text {-cymene }) \mathrm{Cl}_{2}\right]_{2}, \quad 2,2$ '-bipyridine, $\quad \mathrm{AgPF}_{6}$, paraformaldehyde, acetonitrile) were purchased from Sigma Aldrich and used without further purification. The complex $\left[\mathrm{Ag}(\mathrm{bpy})_{2}\right] \mathrm{PF}_{6}$ used for the preparation of the target complex 2 was prepared as a literature-reported procedure. ${ }^{[4]}$ All manipulations were carried out under an open atmosphere otherwise stated. All solvents were distilled over appropriate drying agents and $\mathrm{N}_{2}$-saturated prior to use. NMR spectra were measured on a Bruker 200 and $100.5 \mathrm{MHz}$ spectrometer at $25{ }^{\circ} \mathrm{C}$ with tetramethylsilane as an internal standard. The J values were measured in $\mathrm{H}_{z}$. The elemental analyses were performed using a Perkin-Elmer 2400 Series-II CHN analyzer. Electronic and emission spectra of the complex were obtained on a Shimadzu UV-1601 and Perkin-Elmer-LS 55 luminescence spectrometer respectively. Ligand 1 (Scheme-1) has been prepared as a slightly modified literature-reported procedure ${ }^{[46,48,49]}$ Molecular optimization and time-dependent DFT were done by adopting B3LYP/def2-TZVP basis set with Gaussian $09 \mathrm{~W}$ software. ${ }^{[50]}$ The number of imaginary frequencies of the molecule turned out to be zero, implying minimum energy structures on the potential energy surface. ${ }^{[51}$

\footnotetext{
${ }^{6}$ Department of Chemistry, Visvesvaraya National Institute of Technology, Nagpur 440 010, Maharashtra, India.

$¥$ Currently working at Quality Control Laboratory at Indian Oil Corporation Limited, Haldia Refinery, Haldia 721606, West Bengal, India.

*E-mail: rana_bidyut@yahoo.com, rana1985bidyut@gmail.com (B K Rana); joydevdinda@gmail.com (J. Dinda)
}

55] The theoretical spectrum was studied in the acetonitrile solvent phase. To know the orbital information towards the UV-Vis transitions, TDDFT methodology was implemented in G09W, within the density functional theory framework. To know how the ligands and metal contribute towards the formation total frontier molecular orbital of the complex, Gauss Sum software was used to calculate the partial density of states (PDOS). Here, we have separated the whole complex into several fragments. Solvent medium $\left(\mathrm{CH}_{3} \mathrm{CN}\right)$ calculation has been performed with the help of the polarizable continuum model (PCM) embedded in Gaussian09. Different electronic transitions within the FMOs were obtained using Gauss Sum software. ${ }^{[56]}$ The intensity $v s$ wavelength data obtained from computation was then plotted with the experimental data using ORIGIN software. ${ }^{[57]}$ Different color code was used in ORIGIN to distinguish different spectra. The frontier molecular orbitals of the complex were generated in Gauss view using the same level of theory.

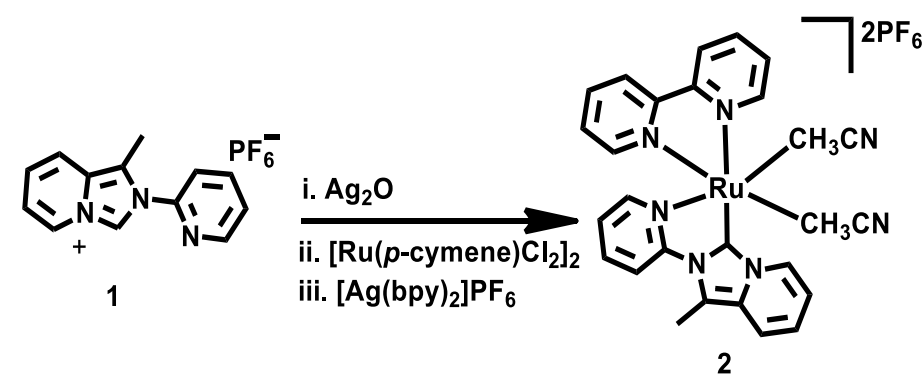

Scheme 1. Synthesis of $\left[\mathrm{Ru}(\mathrm{bpy})(\mathrm{NHC})\left(\mathrm{CH}_{3} \mathrm{CN}\right)_{2}\right]\left[\mathrm{PF}_{6}\right]_{2}$.

Hirshfeld surface analysis is also done for complex 2. The molecular Hirshfeld surface is built on the basis of electron density distribution on the spherical atom. ${ }^{[58,59]}$ The Hirshfeld surface is unique for a given crystal structure and a set of spherical atomic electron densities. It is this property that indicates the possibility of gaining additional insight into the intermolecular interaction of molecular crystals. ${ }^{[60]}$ On the Hirshfeld surfaces, distances $d_{e}$ and $d_{i}$ show the distances from the surfaces to the external nucleus and the surface to the internal nucleus, respectively. The combination of $d_{e}$ and $d_{i}$ as a 2D fingerprint plot summarizes intermolecular contacts in the crystal. ${ }^{[61]}$ The Hirshfeld surfaces $d_{\text {norm }}, d_{e}$, curvedness, shape index, and two-dimensional (2D) fingerprint plots were developed using the 'Crystal Explorer 17.5' application to visualize the intermolecular interaction in this molecule. ${ }^{[62]}$

\subsection{Synthesis of proligand}

The proligand 1-methyl-2-pyridin-2-yl-2H-imidazo[1,5-a] pyridin-4-ylidene (1) was prepared by the formulative cyclization reaction of corresponding Schiff base 2-pyridyl-N(2-acetylpyridyl) methylamine $(250 \mathrm{mg}, 13.6 \mathrm{mmol})$ with crushed $91 \%$ paraformaldehyde powder $(450 \mathrm{mg}, 13.6 \mathrm{mmol})$ in $30 \mathrm{~mL}$ 1,4-dioxane, followed by adding $0.5 \mathrm{~mL}$ triethyl orthoformate, 2-3 drops of formic acid and $4 \mathrm{M} \mathrm{HCl}$ using slightly modified procedures. ${ }^{[46-49]}$ The characterization data and yield were consistent with literature reports. 


\subsection{Synthesis of $\left[\mathrm{Ru}(\mathrm{bpy})(\mathrm{NHC})\left(\mathrm{CH}_{3} \mathrm{CN}\right)_{2}\right]\left[\mathrm{PF}_{6}\right]_{2}$}

In $10 \mathrm{~mL}$ of acetonitrile, the ligand $1(150 \mathrm{mg}, 0.42 \mathrm{mmol})$ and $\mathrm{Ag}_{2} \mathrm{O}(45 \mathrm{mg}, 0.19 \mathrm{mmol})$ were stirred for $4 \mathrm{hrs}$ in dark and then filtered through G-4 gouch plug with celite to get a clear solution of $\mathrm{Ag}(\mathrm{I})-\mathrm{NHC}$ complex. [ $\mathrm{Ru}(p$-cymene $\left.) \mathrm{Cl}_{2}\right]_{2}(150 \mathrm{mg}$, $0.25 \mathrm{mmol}$ ) was dissolved in the minimum amount of acetonitrile, in which the prepared $\mathrm{Ag}(\mathrm{I})-\mathrm{NHC}$ complex solution was added dropwise. An immediate color change was observed from radish yellow to straw yellow. The solution was filtered to remove the $\mathrm{AgCl}$. The resulting solution was evaporated to dryness under reduced pressure and recrystallized from acetonitrile/diethyl ether. An orangeyellowish microcrystalline product was separated by filtration and washed several times with petroleum ether to remove impurities. The yield was $87 \%(250 \mathrm{mg}, 0.43 \mathrm{mmol})$. The prepared $\mathrm{Ru}$ (II)-NHC complex (140 mg, $0.25 \mathrm{mmol}$ ) was taken in $15 \mathrm{~mL}$ acetonitrile and the preprepared $\left[\mathrm{Ag}(\mathrm{bpy})_{2}\right]\left[\mathrm{PF}_{6}\right](190 \mathrm{mg}, 0.32 \mathrm{mmol})$ in $5 \mathrm{~mL}$ acetonitrile was added dropwise to $\mathrm{Ru}(\mathrm{II})-\mathrm{NHC}$ under the stirring condition at room temperature. White precipitation of $\mathrm{AgCl}$ was observed immediately, and the stirring was continued for another $4 \mathrm{hrs}$. After filtration of $\mathrm{AgCl}$, a wine-red solution was obtained, the solvent was removed, and the target compound 2 was dried over silica. The compound was recrystallized from $\mathrm{CH}_{3} \mathrm{CN}$ $/ \mathrm{Et}_{2} \mathrm{O}$. The yield was $70 \%(120 \mathrm{mg}, 0.18 \mathrm{mmol})$.

${ }^{1} \mathrm{HNMR}$ (DMSO-d $\left.6,25^{\circ} \mathrm{C}, 200 \mathrm{Mz}\right) \delta: 9.42(\mathrm{~d}, J=4.6 \mathrm{~Hz}$, $\left.2 \mathrm{H}, \mathrm{H}^{\mathrm{i}, j^{\prime}}\right), 8.90\left(\mathrm{~d}, J=8.0 \mathrm{~Hz}, 1 \mathrm{H}, \mathrm{H}^{\mathrm{a}}\right), 8.69(\mathrm{~d}, J=7.8 \mathrm{~Hz}, 2 \mathrm{H}$, $\left.\mathrm{H}^{\mathrm{m}, \mathrm{m}^{\prime}}\right), 8.50-8.31\left(\mathrm{~m}, 2 \mathrm{H}, \mathrm{H}^{\mathrm{l}, \mathrm{l}^{\prime}}\right), 8.04-7.97\left(\mathrm{~d}-\mathrm{t}, 1 \mathrm{H}, \mathrm{H}^{\mathrm{d}}\right), 7.78-$ $7.58\left(\mathrm{~m}, 4 \mathrm{H}, \mathrm{H}^{\mathrm{c}, \mathrm{e}, \mathrm{f}, \mathrm{h}}\right), 7.28-7.21\left(\mathrm{~m}, 2 \mathrm{H}, \mathrm{H}^{\mathrm{k}, \mathrm{k}^{\prime}}\right), 7.03(\mathrm{t}, J=16.0$ $\left.\mathrm{Hz}, 1 \mathrm{H}, \mathrm{H}^{\mathrm{g}}\right), 6.86\left(\mathrm{t}, J=14.0 \mathrm{~Hz}, 1 \mathrm{H}, \mathrm{H}^{\mathrm{b}}\right), 2.40\left(\mathrm{~s}, 3 \mathrm{H},-\mathrm{CH}_{3}\right.$ $\left.{ }^{\mathrm{i}}\right) .{ }^{13} \mathrm{CNMR}$ (DMSO-d $6,100.5 \mathrm{MHz}, 25^{\circ} \mathrm{C}$ ) $\delta: 150.4,147.4$, $144.5,144.2,142.2,139.0,138.6,137.7,130.5,130.2,129.9$, $128.1,127.6,127.5,127.4,126.7,125.3,122.6,122.0,118.6$, 116.0, 115.7, 115.4, 9.6. Anal. calcd. for $\mathrm{C}_{27} \mathrm{H}_{25} \mathrm{~F}_{12} \mathrm{~N}_{7} \mathrm{P}_{2} \mathrm{RuC}_{24} \mathrm{H}_{20} \mathrm{AgN}_{4} \mathrm{PF}_{6}, \mathrm{C}, 38.67 ; \mathrm{H}, 3.01 ; \mathrm{N}, 11.69$; Found C, 38.64; H, 3.00; N, 11.65\%.

\section{Results and discussions}

\subsection{Synthesis and characterization}

The imidazolium salt precursor, 1-Methyl-2-pyridin-2-yl-2Himidazo[1,5-a] pyridine-4-ylium hexafluorophosphate (1), was prepared by the formative cyclization reaction of the corresponding Schiff base 2-pyridyl-N-(2-acetylpyridyl) methylamine with paraformaldehyde, tri-ethyl ortho-formate, and $4 \mathrm{M} \mathrm{HCl}$ as previously reported procedures. ${ }^{[46]} \mathrm{Ru}(\mathrm{II})$ complex 2 is prepared via the silver carbene transfer method which is very common in NHC chemistry. Treatment of the proligand (1) with $\mathrm{Ag}_{2} \mathrm{O}$ in acetonitrile at room temperature gives the silver complex $\mathrm{Ag}(\mathrm{NHC})_{2} \mathrm{PF}_{6}$. After isolation of the Ag-complex applying reported procedures, ${ }^{[63]}$ it was treated with a stoichiometric amount of $\left[\mathrm{Ru}(p \text {-cymene }) \mathrm{Cl}_{2}\right]_{2}$ in acetonitrile, stirring after some time, the solution changes from reddish yellow to straw yellow with the precipitation of $\mathrm{AgCl}$. After filtration, the $\mathrm{Ru}(\mathrm{II})-\mathrm{NHC}$ obtained in very good yield $(87 \%)$. Finally, the treatment of complex Ru (II)-NHC with $\left[\mathrm{Ag}(\mathrm{bpy})_{2}\right]\left[\mathrm{PF}_{6}\right]$ affords the targeted complex $\left[\mathrm{Ru}(\mathrm{bpy})(\mathrm{NHC})\left(\mathrm{CH}_{3} \mathrm{CN}\right)_{2}\right]^{+2}(2)$, as shown in Scheme 1 with a very good yield of $75 \%$. Complex 2 was characterized by the ${ }^{1} \mathrm{HNMR}$ and ${ }^{13} \mathrm{CNMR}$ spectroscopy. The formation of the $\left[\mathrm{Ru}(\mathrm{bpy})(\mathrm{NHC})\left(\mathrm{CH}_{3} \mathrm{CN}\right)_{2}\right]^{+2}$ complex 2 was confirmed by the absence of the diagnostic imidazolium -NCHN peak in ${ }^{1} \mathrm{HNMR}$ signal associated with the imidazolium precursor (free ligand-NCHN; $\delta 10.12 \mathrm{ppm}\left(\mathrm{s}\right.$ ), in DMSO-d $\mathrm{d}_{6}$ ) and the downfield shift of $\alpha$-pyridyl proton that observed at $8.90 \mathrm{ppm}$ (free ligand $8.75 \mathrm{ppm}$ ). ${ }^{13} \mathrm{CNMR}$ spectroscopic analysis revealed that carbonic carbon appears at $174.6 \mathrm{ppm}$ (free ligand at $150.4 \mathrm{ppm}$ ); a downfield shift suggested the $\mathrm{C}_{\text {carbene }}$ atom coordinated to a Ru (II) center. The signals of 2,2'-bpy appear at 9.42, 8.69, and $8.50 \mathrm{ppm}$. Good execution of downfield shift for most of the aromatic protons was observed as compared to the analogous signals recorded in $\mathrm{Ru}$ (II)complex 2. X-ray diffraction (XRD) studies, as shown in Fig. 1 , confirmed the expected geometry of complex 2 . The fine long needle-shaped crystals of 2 are crystallized as a 'triclinic crystal system' in the ' $P$-1' space group. Additional structural support of complex 2 was obtained from spectroscopic studies, the absorbance maxima $\left(\lambda_{\max }\right.$ ) at 238 and $271 \mathrm{~nm}$ (with a hump of $420 \mathrm{~nm}$ ) and photoluminescent maxima at $430 \mathrm{~nm}$ (Fig. 7) display that the absorption bands are red-shifted due to the presence of bipyridyl group.

\subsection{X-ray crystal structure analysis of compound 2}

Additional support for the proposed geometry of complex 2 was confirmed by single-crystal X-ray diffraction studies. Single crystals of 2 suitable for X-ray diffraction were grown by the slow diffusion of diethyl ether into a saturated acetonitrile solution of complex 2. The obtained crystallographic data and structure refinement details are listed in Table 1 and the corresponding bond parameters are listed in Table ST- 1 of the supplementary information file. The lattice parameters are $a=12.5887(3) \AA, b=14.6129(3) \AA, c=$ 18.9820(5) $\AA, \alpha=107.5648(9)^{\circ}, \quad \beta=92.3910(8)^{\circ}, \gamma=$ $91.9845(11)^{\circ}, \mathrm{V}=3322.09(14) \AA^{3}$. The asymmetric unit of the title compound, drawn at $20 \%$ ellipsoidal probability, is depicted in Fig. 1. There are two molecules of the ruthenium complex and four molecules of the counter anion, $\mathrm{PF}_{6}$ in the asymmetric unit. In the presence of $\mathrm{N} \cap \mathrm{C}$ donor bidentate ligand in $\mathrm{Ru}(\mathrm{II})-\mathrm{NHC}$ complex 2, the $\mathrm{Ru}-\mathrm{C}_{\text {carb }}$ bond distance $\mathrm{Ru}(1 \mathrm{~A})-\mathrm{C}(1 \mathrm{~A})=1.988(6) \AA$ is shorter than similar $\mathrm{Ru}-\mathrm{C}_{\text {carb }}$ distance $2.033(3) \AA$ reported in $\left[\mathrm{Ru}(\mathrm{bpy})_{2}(\mathrm{NHC})\right]^{+2}$ complex bearing $\mathrm{N} \cap \mathrm{C}$ donor ligand. ${ }^{[64]} \mathrm{Ru}-\mathrm{N}_{\mathrm{bpy}}$ distances in present case $\mathrm{Ru}(1 \mathrm{~A})-\mathrm{N}(4 \mathrm{~A})=2.048(5) \AA$ and $\mathrm{Ru}(1 \mathrm{~A})-\mathrm{N}(5 \mathrm{~A})=$ $2.115(5) \AA$ are comparable to the reported distances. ${ }^{[65,66]}$ The $\mathrm{Ru}-\mathrm{N}_{\mathrm{py}}$ distance $\mathrm{Ru}(1 \mathrm{~A})-\mathrm{N}(3 \mathrm{~A})=2.061(5) \AA$ distance is close to $\mathrm{Ru}-\mathrm{N}_{\mathrm{bpy}}$ distances in 2 .

The complex displays the coordination geometry very close to a distorted octahedral geometry. The $\mathrm{C}(1 \mathrm{a})-\mathrm{Ru}(1 \mathrm{a})$ $\mathrm{N}(5 \mathrm{a}), \mathrm{N}(3 \mathrm{~A})-\mathrm{Ru}(1 \mathrm{~A})-\mathrm{N}(6 \mathrm{~A})$ and $\mathrm{N}(4 \mathrm{~A})-\mathrm{Ru}(1 \mathrm{~A})-\mathrm{N}(7 \mathrm{~A})$, angles are 173.3(2), 176.6(2) and 174.1(2) deviated from linearity; whereas the other angles $\mathrm{C}(1 \mathrm{~A})-\mathrm{Ru}(1 \mathrm{~A})-\mathrm{N}(3 \mathrm{~A})$, 


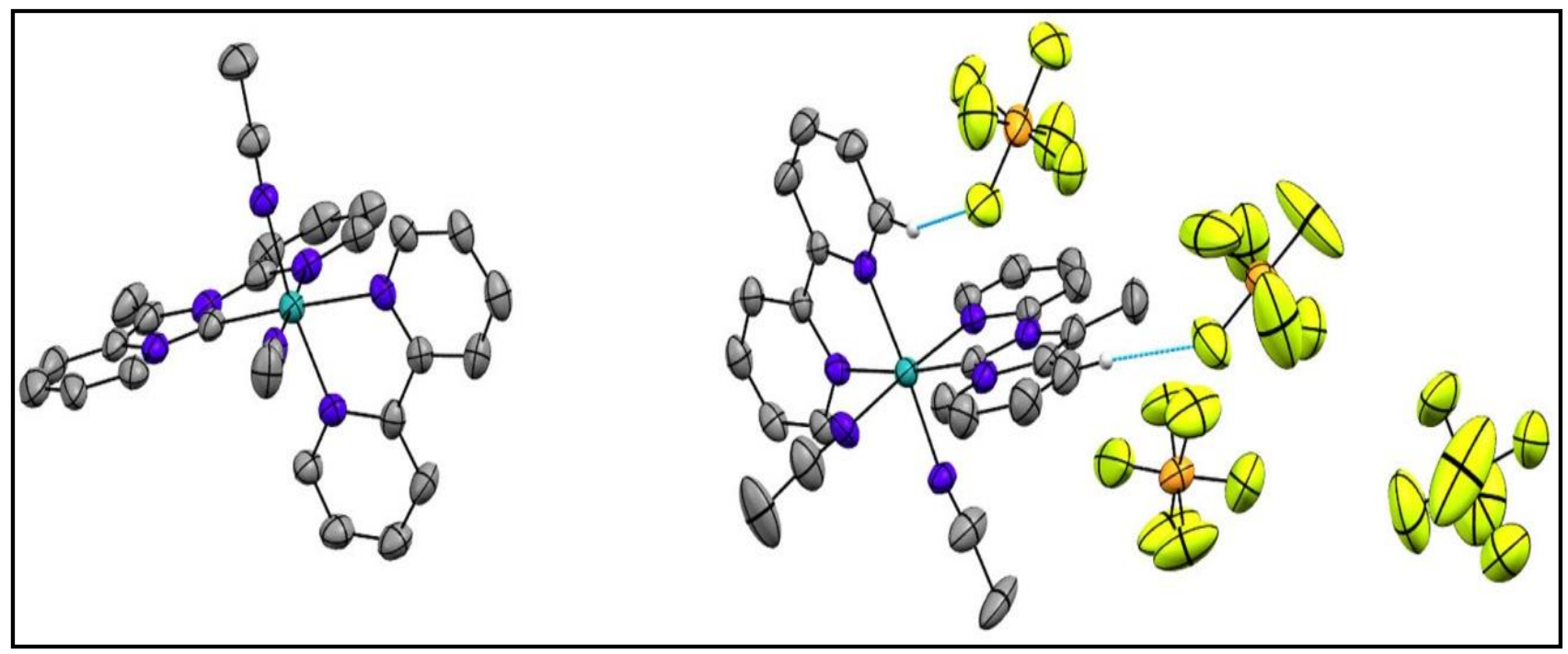

Fig. 1 The asymmetric unit of the complex drawn at 20\% ellipsoidal probability. The dotted lines indicate intermolecular C-H...FH-bonds.

Table 1. Crystallographic details of the complex 2.

\begin{tabular}{|c|c|}
\hline Complex 2 & Data \\
\hline Formula & $\mathrm{C}_{27} \mathrm{H}_{25} \mathrm{~F}_{12} \mathrm{~N}_{7} \mathrm{P}_{2} \mathrm{Ru}$ \\
\hline Formula weight & 838.55 \\
\hline Temperature/K & 295 \\
\hline Wavelength $(\AA)$ & 0.71073 \\
\hline Crystal system & Triclinic \\
\hline Space group & $P-1$ \\
\hline$a(\AA)$ & $12.5887(3)$ \\
\hline$b(\AA)$ & $14.6129(3)$ \\
\hline$c(\AA)$ & $18.9820(5)$ \\
\hline$\alpha\left(\left(^{\circ}\right)\right.$ & $107.5648(9)$ \\
\hline$\beta\left(^{\circ}\right)$ & $92.3910(8)$ \\
\hline$\gamma\left({ }^{\circ}\right)$ & $91.9845(11)$ \\
\hline $\mathrm{V}\left(\AA^{3}\right)$ & $3322.09(14)$ \\
\hline $\mathrm{Z}^{\prime}, \mathrm{Z}$ & 2,4 \\
\hline Density $\left(\mathrm{g} \mathrm{cm}^{-3}\right)$ & 1.677 \\
\hline$\mu\left(\mathrm{mm}^{-1}\right)$ & 0.667 \\
\hline $\mathrm{F}(000)$ & 1672 \\
\hline$\theta(\min , \max )$ & $2.83,25.00$ \\
\hline $\mathrm{h}_{\min }, \max , \mathrm{k}_{\min }, \max , 1_{\min }, \max$. & $-14,14 ;-17,17 ;-21,22$ \\
\hline No. of refl. & 34135 \\
\hline No of unique ref./Obs. ref. & $11653 / 7699$ \\
\hline No. parameters & 889 \\
\hline $\mathrm{R}_{\text {all }}, \mathrm{R}_{\mathrm{obs}}$ & $0.1109,0.0709$ \\
\hline wRall,wRobs & $0.2229,0.1932$ \\
\hline$\Delta \rho_{\max , \min }$ & $0.922,-0.663$ \\
\hline G.o.F. & 1.040 \\
\hline CCDC No. & 2008104 \\
\hline
\end{tabular}

$\mathrm{N}(3 \mathrm{~A})-\mathrm{Ru}(1 \mathrm{~A})-\mathrm{N}(4 \mathrm{~A}), \quad \mathrm{N}(4 \mathrm{~A})-\mathrm{Ru}(1 \mathrm{~A})-\mathrm{N}(5 \mathrm{~A}), \quad \mathrm{N}(5 \mathrm{~A})-$ $\mathrm{Ru}(1 \mathrm{~A})-\mathrm{N}(6 \mathrm{~A}), \mathrm{N}(3 \mathrm{~A})-\mathrm{Ru}(1 \mathrm{~A})-\mathrm{N}(7 \mathrm{~A}), \mathrm{N}(7 \mathrm{~A})-\mathrm{Ru}(1 \mathrm{~A})-\mathrm{C}(1 \mathrm{~A})$ are 78.4(3), 91.7(2), 77.81(19), 85.0(2), 88.5(2) and 88.4(2) ${ }^{\circ}$ respectively indicate that complex 2 bears a distorted octahedral geometry (Fig. 2, Table ST-1).

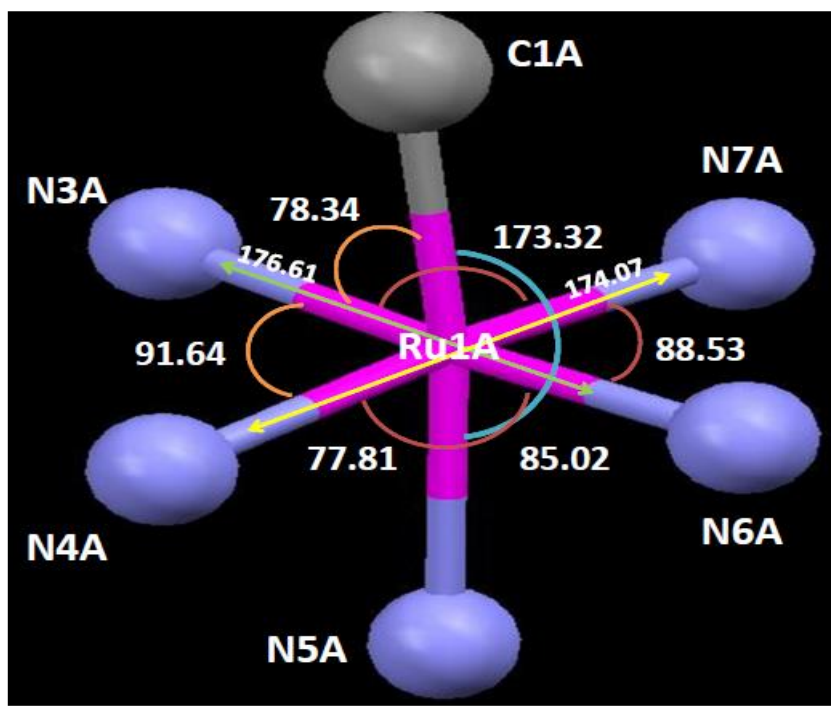

Fig. 2 Representation of deviation from octahedral geometry around $\mathrm{Ru}(\mathrm{II})$ in 2 .

One such molecule of the metal complex is held with two different counterions via $\mathrm{C}-\mathrm{H} \cdots \mathrm{F}^{-} \mathrm{H}$-bonds, with the $\mathrm{H} \cdots \mathrm{F}$ distances in the asymmetric unit lying in the range of $2.42 \sim$ $2.47 \AA$. The crystal packing involves the formation of a complex network of C-H $\cdots \mathrm{F}^{-} \mathrm{H}$-bonds (Table ST-2) between different molecules of the asymmetric unit with the symmetryrelated molecules in the crystal. It is of extreme importance to know that the distance between the donor hydrogen atoms and the acceptor fluorine atoms, lying in the range of $2.42 \sim 2.47$ $\AA$, is sufficiently short in comparison to the sum of the van der Waals radii of the participating atoms (the sum is $2.67 \AA$ ). ${ }^{[67]}$ This may be on account of the favorable electrostatic contributions that govern interactions between the negatively charged fluorine atoms, of the anionic moiety, and the positively charged metal-ligand complex, that induces the electropositive character on the H-atoms of the ligand 


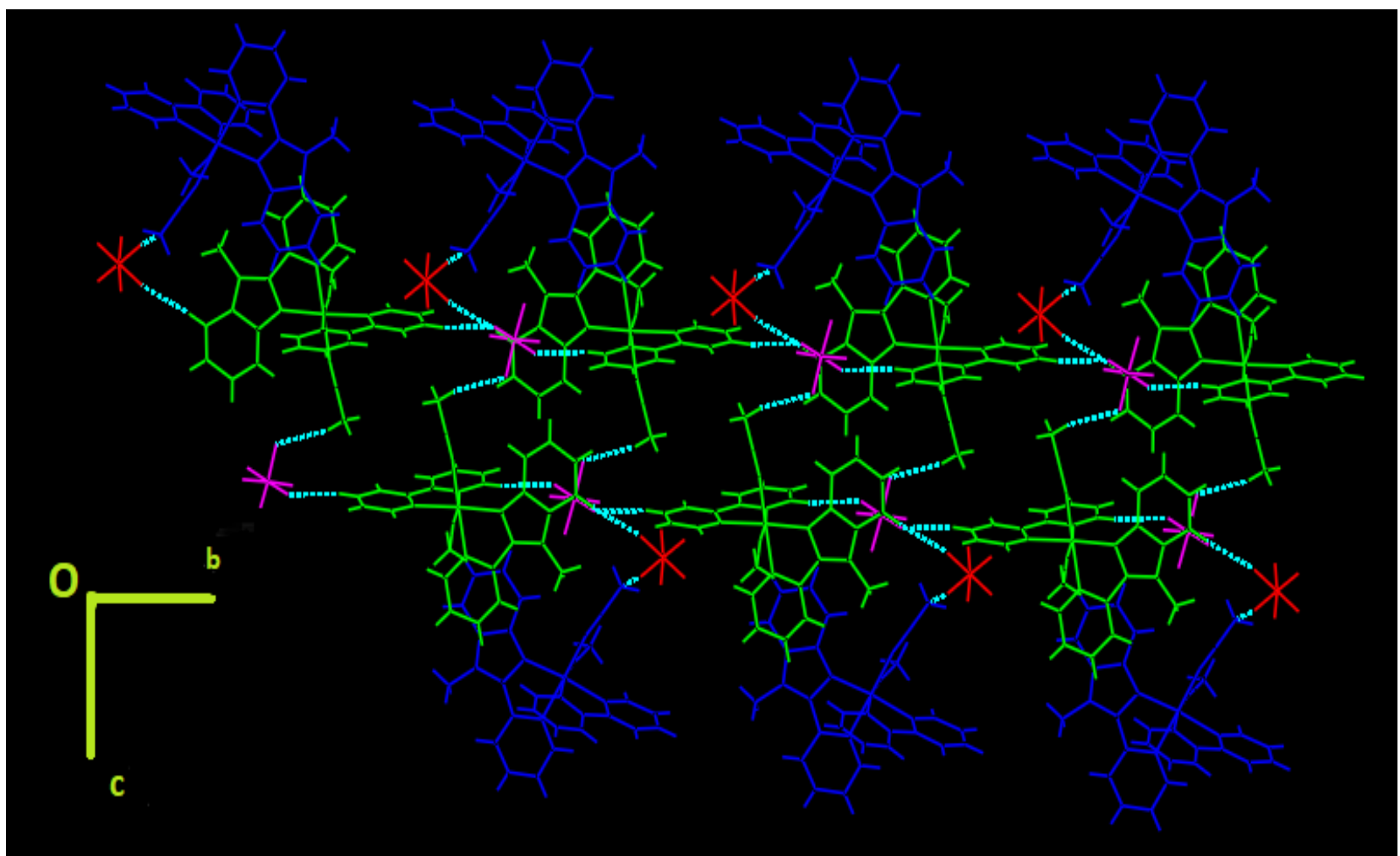

Fig. 3 The crystal packing with various $\mathrm{C}-\mathrm{H}$.... $\mathrm{F}^{-}$weak H-bonding interactions of the Ru-(bpy) complex down the bc-plane. Molecule A: Blue; Molecule B: Green; Molecule C and D: Red and Pink (two $\mathrm{PF}_{6}{ }^{-}$) ions in the vicinity of the complex. Dotted lines indicate intermolecular interactions.

backbone. Molecules of B-type (green in color) are connected via such $\mathrm{H}$-bonds with two $\mathrm{PF}_{6}$ units, corresponding to molecule $\mathrm{C}$ (red in color) and $\mathrm{D}$ (pink in color). The supramolecular structure involving Molecule $\mathrm{B}$ (green in color) and one $\mathrm{PF}_{6}$ unit i.e., molecule $\mathrm{D}$ (pink in color) form a tetrameric $R_{4}^{4}(22)$ close ring motif, ${ }^{[68]}$ which further propagates along the $b c$-plane (Fig. 3). Molecules of A-type (blue in color) are connected via similar $\mathrm{H}$-bonds to a separate $\mathrm{PF}_{6}{ }^{-}$unit, corresponding to molecule $\mathrm{C}$ (red in color), as shown in Fig. 3.

\subsection{Hirshfeld surface analysis}

The Hirshfeld surfaces of the crystal structure were investigated to illustrate the nature of intermolecular interactions, which mapped over $d_{e}, d_{n o r m}$, shape index, and curvedness shown in Fig. 4 . In the $d_{\text {norm }}$ surfaces, the large red color spot shows the hydrogen bonding $\mathrm{H} \cdots \mathrm{F}$ contacts whereas the blue surface area represents the $\mathrm{H} \cdots \mathrm{H}$ contacts (Fig. 4b). The $d_{e}$ surface features appear as a relatively flat green region where the contact distances are similar (Fig. 4a). The shape-index surfaces measure the donor-acceptor pair and curvedness surfaces measure how much shape effectively divides the surfaces into a set of patches. The absence of a triangle curved in both the shape-index surface and curvedness surface represents the absence of $\pi \cdots \pi$ contacts. The adjacent highlighted red and yellow regions on the shape index surface also show the strong hydrogen bonding interactions present in the molecule (Fig. 4c).
However, the blue curved and yellow regions on the curvedness surfaces shows the $\mathrm{H} \cdots \mathrm{H}$ interactions (Fig. 4d). The Hirshfeld surfaces show red spot due to $\mathrm{C}-\mathrm{H}^{\cdots} \cdot \mathrm{F}^{-}$ hydrogen bonding. The 2D fingerprint plot shows the sharp spike, which represents the strong hydrogen bonding present in the molecule (Fig. 5a). The fingerprint plot shows that the $\mathrm{H} \cdots \mathrm{F}$ contacts have a relatively higher contribution of $35 \%$ in comparison to other interactions. Further, the percentage contributions of other intermolecular interactions in this crystal structure are as follows: $\mathrm{H} \cdots \mathrm{H}(34.7 \%), \mathrm{C} \cdots \mathrm{H} / \mathrm{H} \cdots \mathrm{C}$ $(18.8 \%), \mathrm{C} \cdots \mathrm{F} / \mathrm{F} \cdots \mathrm{C}(4.9 \%), \mathrm{N} \cdots \mathrm{H} / \mathrm{H} \cdots \mathrm{N}$ (3.3\%), $\mathrm{C} \cdots \mathrm{C}$ (2.4\%) (Fig. 5b).

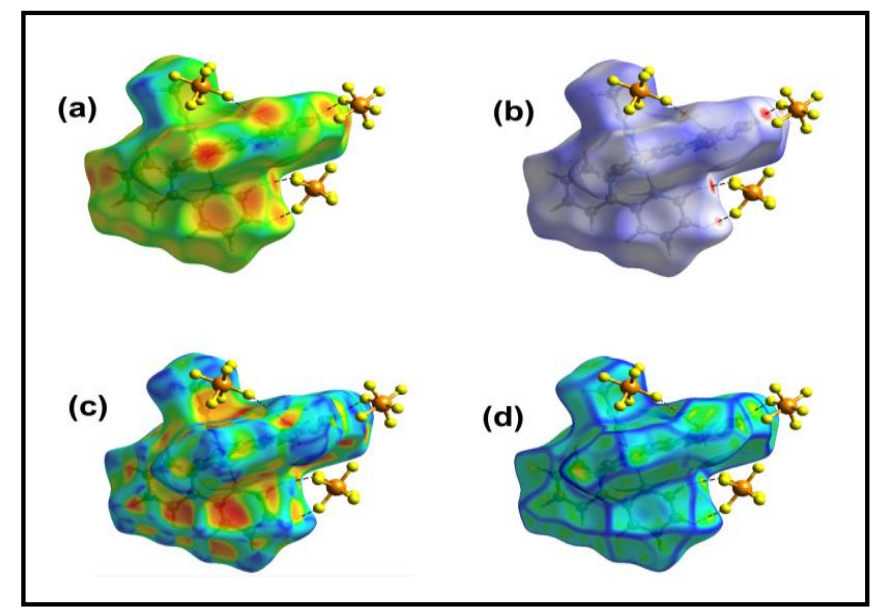

Fig. 4 Hirshfeld surfaces mapped with (a) $d_{e}$, (b) $d_{\text {norm, }}$ (c) shapeindex, and (d) curvedness for the compound. 


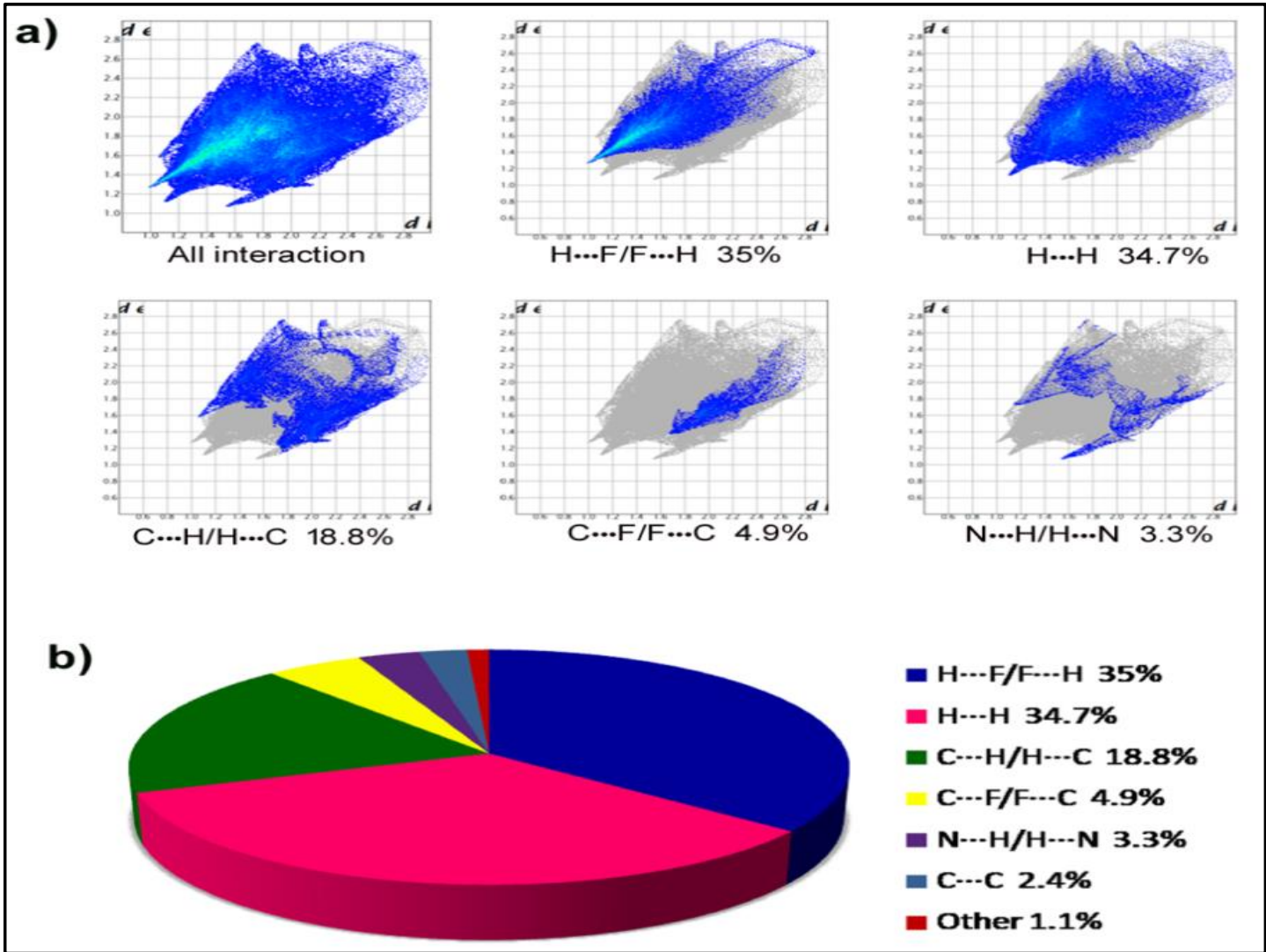

Fig. 5 (a) The 2D fingerprint plots of the metal complex; (b) The short contact contributions derived from H...F/F...H, C...H/H...C, $\mathrm{C} \ldots \mathrm{F} / \mathrm{F} \ldots \mathrm{C}, \mathrm{N} \ldots \mathrm{H} / \mathrm{H} \ldots \mathrm{N}, \mathrm{C} \ldots \mathrm{C}$ and $\mathrm{H} \ldots \mathrm{H}$ contacts.

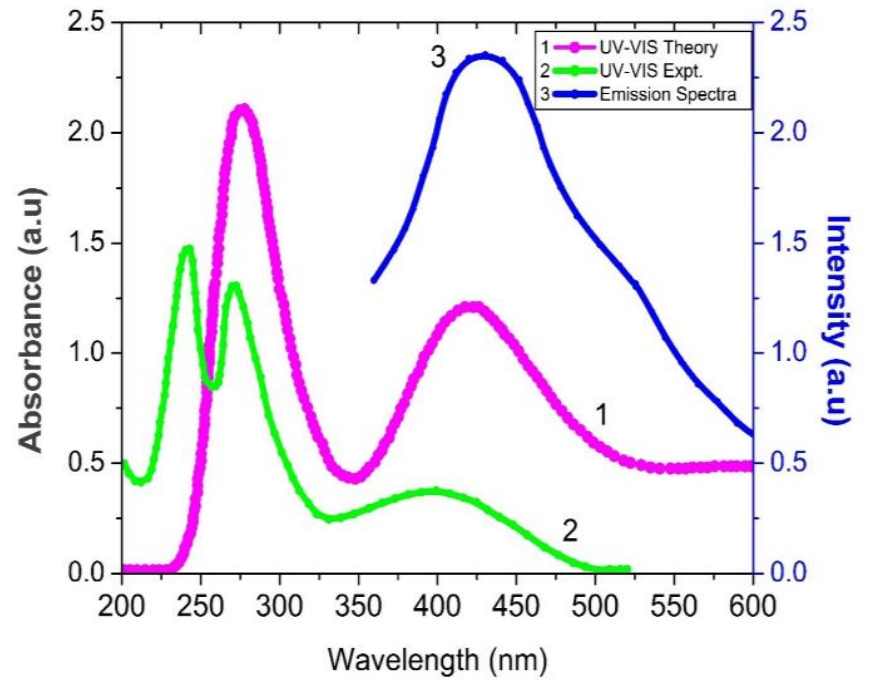

Fig. 6 Absorption spectra (left; experimental in green color and theoretical in pink color) and emission spectra (right, in blue color) is of complex 2 .

\subsection{Spectroscopic studies}

The UV-Vis absorption spectrum for complex 2 was recorded in acetonitrile solvent at room temperature shown in Fig. 6 (green). The mononuclear complex shows weak interaction bands at 235-420 $\mathrm{nm}$ due to the inter-ligand charge transfer (ILCT)bpy $\rightarrow \mathrm{NHC}$ and metal-to-ligand charge transfer (MLCT) from $\mathrm{t}_{2 \mathrm{~g}}$ to $\delta^{*}$, whose energy varies with the nature of the ligand acting as an acceptor. ${ }^{[6,70]}$ Complex 2 shows two sharp absorbance bands $\left(\lambda_{\max }\right)$ at 238 and $271 \mathrm{~nm}$ with a hump at $399 \mathrm{~nm}$ (the calculated transitions (pink) at $278-285 \mathrm{~nm}$ and $423 \mathrm{~nm}$ ). The absorption bands at 238 and $271 \mathrm{~nm}$ have also been tentatively assigned to MLCT [Ru (II) $\rightarrow \partial^{*}$ arene]. The band in the region $399 \mathrm{~nm}$ may exhibit a small solvent effect or indication of luminescent spectra due to the presence of a bipyridyl group in the ligand. The photoluminescence property of complex 2 has been studied in acetonitrile at room temperature. Complex 2 shows strong luminescent spectra at $430 \mathrm{~nm}$ upon excitation at $400 \mathrm{~nm}$ due to the presence of a bipyridyl group. The emission spectrum of complex 2 is shown in Fig. 6 (blue).

Theoretical studies of absorption spectra of Ru (II)-NHC complex 2 in acetonitrile solvent are shown in Fig. 6 (pink), and significant transition values of absorption spectra are listed in Table 2. The moderately intense band at $238-271 \mathrm{~nm}$ is owing to metal-ligand transitions. However, the absorption bands near $399 \mathrm{~nm}$ could have a substantial ligand contribution to the complex. The absorption maxima for complex $2\left(\lambda_{\max }=285 \mathrm{~nm}\right)$ are found in between the reported complex. ${ }^{[71]}$ The absorption maxima of 2 are due to the $\sigma$ donor and weak $\pi$-acceptor character of the NHC ligand compared to the bi-dentate 'bpy' ligand. ${ }^{[14]}$ The MLCT-type transitions in the absorption spectra are supported by computational calculations [Fig. 6, Table 2] in the DFT platform. ${ }^{[72]}$ 
Table 2. Major transition values for absorption spectra of complex 2. (Experimental and theoretical data).

\begin{tabular}{|c|c|c|c|}
\hline \multicolumn{2}{|c|}{ Wavelength (nm) } & \multirow{2}{*}{$\begin{array}{l}\text { Osc. } \\
\text { Strength }\end{array}$} & \multirow[t]{2}{*}{ Major Transitions } \\
\hline Expt. & Theory & & \\
\hline 238 & 278 & 0.1357 & $\begin{array}{l}\text { HOMO-5->LUMO }(12 \%), \\
\text { HOMO-3->LUMO+3(19\%), } \\
\text { HOMO-1->LUMO+6(47\%) }\end{array}$ \\
\hline 271 & 285 & 0.0917 & $\begin{array}{l}\text { HOMO-3->LUMO+2(49\%), } \\
\text { HOMO-2->LUMO+3(24\%) }\end{array}$ \\
\hline 399 & 423 & 0.1888 & HOMO->LUMO+13 (87\%) \\
\hline
\end{tabular}

The theoretical $\lambda_{\max }$ values $30 \sim 40 \mathrm{~nm}$ varied from experimental values. The calculated transitions at $278-285 \mathrm{~nm}$ (238-271 nm in expt.) involve a significant contribution from $\mathrm{HOMO}-1 \rightarrow \mathrm{LUMO}+6$ (47 \%), HOMO-3 $\rightarrow$ LUMO+2 (49\%), and HOMO-2 $\rightarrow$ LUMO+3 (24\%). Transitions at $423 \mathrm{~nm}(399$ $\mathrm{nm}$ in expt.) involve $\mathrm{HOMO} \rightarrow \mathrm{LUMO}+13$ (87\%) (Table 2). To get an insight into the structure bonding correlation on the electronic transition of absorption spectra, the metal and ligand contributions to the formation of FMOs were also calculated $^{[73-75]}$ using the B3LYP/def2-TZVP level of theory (Fig. SF-1), and PDOS also analyzed (Fig. 7) using computational techniques. ${ }^{[76-79]}$ The compositions of occupied FMOs show that these have significant ligand contributions both from NHC and bi-pyridine $(47 \sim 49 \%)$ and also Ru metal (25 $77 \%$ ) from HOMO-1 to HOMO-3, and $\mathrm{CH}_{3} \mathrm{CN}$ has a negligible contribution. The unoccupied MOs also exhibit a major share from NHC ligand (LUMO, 49\%; LUMO+2, 72\%), and $b i$-pyridine (LUMO, 45\%; LUMO+4, 85\%) and very less contribution from $\mathrm{CH}_{3} \mathrm{CN}$ (Fig. 7, Table ST-3). Hence, instead of pure ligand characteristics (intra-ligand/inter-ligand) transitions, complex 2 bears a mixed mode of metal-ligand transitions. Under oxygen-free conditions, complex 2 is found to be emissive in $\mathrm{CH}_{3} \mathrm{CN}$ at room temperature at $430 \mathrm{~nm}$ (Fig. $6)$. The emission is due to the presence of a bi-pyridine ligand present in the complex as compared to our previously reported complex. ${ }^{[69,71]}$ Some selective FMOs are shown in Fig. SF-1.

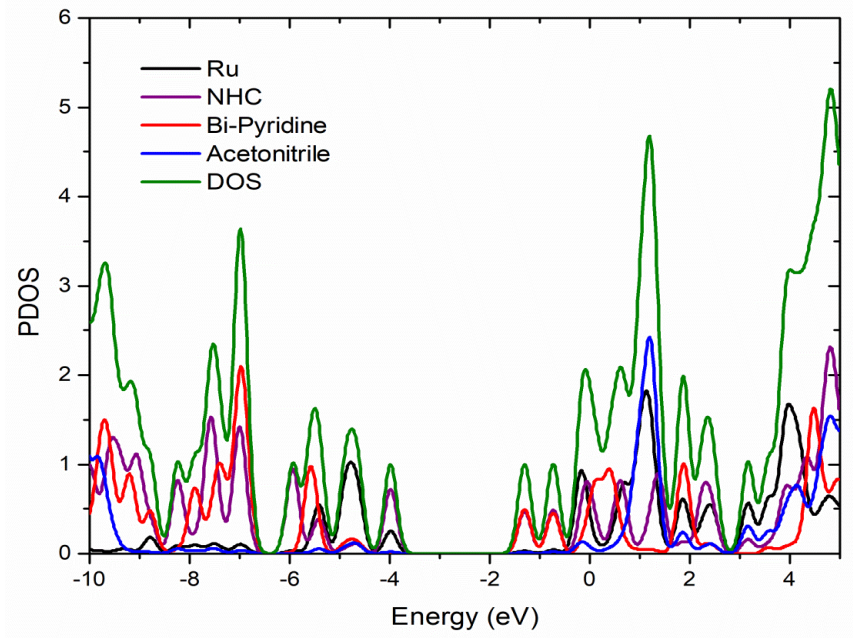

Fig. 7 Partial density of states (PDOS) for complex 2.

\section{Conclusion}

In this present work, we studied the coordination behavior of N-heterocyclic carbene and 2, 2'-bipyridyl ligand. The synthesis, structure, and luminescent properties of 2, 2/bipyridyl Ru (II)-annulated NHC complex of 1-methyl-2pyridin-2-yl-2H-imidazo[1,5-a] pyridin-4-ylidene are described. The distorted octahedral geometry of complex 2 has been confirmed by X-ray crystallographic studies. The molecules possess several $\mathrm{C}-\mathrm{H}$.... $\mathrm{F}^{-}$weak H-bonding interactions. Such interactions enrich the crystal engineering design parameters which are used to create higher-order structures. The photophysical properties of the complexes were also examined and found to depend on the ancillary ligands as well as the constituent metals. The peaks are due to ILCT character along with the maximum contribution of MLCT transition in complexes. Such features may find utility in materials used in contemporary electronics applications. Many of the abovementioned assignments were corroborated by a series of DFT and TDDFT calculations which were in good agreement with the experiment. The molecule will be useful for the pro-apoptotic and antimicrobial activity against various cancer cells ${ }^{[71,72,80]}$ and also a useful pre-catalyst for the transfer hydrogenation of ketone ${ }^{[79-82]}$ and also in asymmetric hydrogenation reactions. ${ }^{[83,84]}$

\section{Acknowledgments}

B. Rana is thankful to HIT Haldia, and JU Kolkata, for giving them research facilities and infrastructure during his $\mathrm{Ph} . \mathrm{D}$. work. D. Chopra thanks IISER Bhopal for research facilities and infrastructure. G. Roymahapatra and S. Giri want to thank HIT Haldia, for facilitating the research infrastructure.

\section{Conflict of interest}

There are no conflicts to declare.

\section{Supporting information \\ Applicable.}

\section{References}

[1] S. Stagni, A. Palazzi, S. Zacchini, B. Ballarin, C. Bruno, M. Marcaccio, F. Paolucci, M. Monari, M. Carano, A. J. Bard, Inorganic Chemistry, 2006, 45, 695-709, doi: 10.1021/ic0514905. [2] F. Heinemann, J. Karges, Gilles Gasser, Accounts of chemical research, 2017, 50, 2727-2736, doi: 10.1021/acs.accounts.7b00180.

[3] R. W. Harrigan, G. D. Hager, G. A. Crosby, Chemical Physics Letters, 1973, 21, 487-490, doi: 10.1016/0009-2614(73)80290-8.

[4] J. N. Demas, D. G. Taylor, Inorganic Chemistry, 1979, 18, 3177-3179, doi: 10.1021/ic50201a044.

[5] B. Durham, J. V. Caspar, J. K. Nagle, T. J. Meyer, Journal of the American Chemical Society, 1982, 104, 4803-4810, doi: 10.1021/ja00382a012.

[6] S. D. Inglez, F. C. A. Lima, A. B. F. Silva, A. R. Simioni, A. C. Tedesco, J. F. S. Daniel, B. S. Lima-Neto, R. M. Carlos, Inorganic Chemistry, 2007, 46, 5744-5753, doi: 
10.1021/ic062478v.

[7] E. M. Kober, T. J. Meyer, Inorganic Chemistry, 1984, 23, 3877-3886, doi: 10.1021/ic00192a009.

[8] D. Schleicher, H. Leopold, H. Borrmann, T. Strassner, Inorganic Chemistry, 2017, 56, 7217-7229, doi: 10.1021/acs.inorgchem.7b00831.

[9] T. J. Meyer, Pure and Applied Chemistry, 1986, 58, 1193-1206, doi: $10.1351 /$ pac198658091193.

[10] N. H. Damrauer, G. Cerullo, A. Yeh, T. R. Boussie, C. V. Shank, J. K. McCusker, Science, 1997, 275, 54-57, doi: 10.1126/science.275.5296.54.

[11] J. He, B. Wang, S. Chang, T. Chen, Organometallics and Related Molecules for Energy Conversion, 2015, 91-114, doi: 10.1007/978-3-662-46054-2_4.

[12] A. O. Adeloye, P. A. Ajibade, Molecules, 2014, 19, 12421 12460, doi: 10.3390/molecules190812421.

[13] J. A. Rudd, M. K. Brennaman, K. E. Michaux, D. L. Ashford, R. W. Murray, T. J. Meyer, The Journal of Physical Chemistry A, 2016, 120, 1845-1852, doi: 10.1021/acs.jpca.6b00317.

[14] S. Das Adhikary, T. Samanta, G. Roymahapatra, F. Loiseau, D. Jouvenot, S. Giri, P. K. Chattaraj, J. Dinda, New Journal of Chemistry, 2010, 34, 1974, doi: 10.1039/b9nj00698b.

[15] E. Medina, B. Pinter, Catalysts, 2020, 10, 80, doi: 10.3390/catal10010080.

[16] Q. J. Pan, Y. R. Guo, L. Li, S. O. Odoh, H. G. Fu, H. X. Zhang, Physical Chemistry Chemical Physics, 2011, 13, 14481, doi: 10.1039/c1cp00030f.

[17] M. Fèvre, J. Pinaud, Y. Gnanou, J. Vignolle, D. Taton, Chemical Society Reviews, 2013, 42, 2142, doi: $10.1039 / \mathrm{c} 2 \mathrm{cs} 35383 \mathrm{k}$.

[18] D. Braun, P. Huber, J. Wudy, J. Schmidt, H. Yersin, The Journal of Physical Chemistry, 1994, 98, 8044-8049, doi: 10.1021/j100084a021.

[19] J. T. Hewitt, P. J. Vallett, N. H. Damrauer, The Journal of Physical Chemistry A, 2012, 116, 11536-11547, doi: 10.1021/jp308091t.

[20] W. Humbs, H. Yersin, Inorganic Chemistry, 1996, 35, 2220 2228, doi: 10.1021/ic9510932.

[21] H. Riesen, L. Wallace, E. Krausz, The Journal of Physical Chemistry, 1996, 100, 4390-4394, doi: 10.1021/jp9530414.

[22] H. Riesen, L. Wallace, E. Krausz, The Journal of Physical Chemistry, 1996, 100, 17138-17144, doi: 10.1021/jp961792f.

[23] H. Yersin, C. Kratzer, Coordination Chemistry Reviews, 2002, 229, 75-93, doi: 10.1016/s0010-8545(02)00106-6.

[24] W. K. Tsui, L. H. Chung, M. M. K. Wong, W. H. Tsang, H. S. Lo, Y. Liu, C. H. Leung, D. L. Ma, S. K. Chiu, C. Y. Wong, Scientific Reports, 2015, 5, 9070, doi: 10.1038/srep09070.

[25] D. Schleicher, A. Tronnier, J. Soellner, T. Strassner, European Journal of Inorganic Chemistry, 2019, 2019, 19561965, doi: 10.1002/ejic.201900108.

[26] S. V. Krivovichev, P. C. Burns, I. G. Tananaev, B. F. Myasoedov, 2007, 444, 457-463, doi: 10.1016/j.jallcom.2006.10.077.

[27] D. Schleicher, H. Leopold, H. Borrmann, T. Strassner, Inorganic Chemistry, 2017, 56, 7217-7229, doi: 10.1021/acs.inorgchem.7b00831.

[28] A. J. Arduengo III, R. L. Harlow, M. Kline, Journal of the American Chemical Society, 1991, 113, 361-363, doi: 10.1021/ja00001a054.

[29] J. C. Garrison, W. J. Youngs, Chemical Reviews, 2005, 105, 3978-4008, doi: 10.1021/cr050004s.

[30] F. E. Hahn, M. C. Jahnke, Angewandte Chemie International Edition, 2008, 47, 3122-3172, doi: 10.1002/anie.200703883.

[31] N. Marion, S. D. González, P. D. Frémont, A. R. Noble, S. P. Nolan, Angewandte Chemie International Edition, 2006, 45, 3647-3650, doi:10.1002/anie.200600571.

[32] V. J. Catalano, A. L. Moore, Inorganic Chemistry, 2005, 44, 6558-6566, doi: 10.1021/ic050604+.

[33] H. M. J. Wang, I. J. B. Lin, Organometallics, 1998, 17, $972-$ 975, doi: 10.1021/om9709704.

[34] M. N. Hopkinson, C. Richter, M. Schedler, F. Glorius, Nature, 2014, 510, 485-496, doi: 10.1038/nature13384.

[35] M. Fèvre, J. Pinaud, Y. Gnanou, J. Vignolle, D. Taton, Chemical Society Reviews, 2013, 42, 2142, doi: $10.1039 / \mathrm{c} 2 \mathrm{cs} 35383 \mathrm{k}$.

[36] A. B. Miguel-Coello, M. Bardají, S. Coco, B. Donnio, B. Heinrich, P. Espinet, Inorganic Chemistry, 2018, 57, 4359-4369, doi: 10.1021/acs.inorgchem.7b03178.

[37] K. Nomiya, S. Morozumi, Y. Yanagawa, M. Hasegawa, K. Kurose, K. Taguchi, R. Sakamoto, K. Mihara, N. C. Kasuga, Inorganic Chemistry, 2018, 57, 11322-11332, doi: 10.1021/acs.inorgchem.8b00011.

[38] A. Vellé, A. Cebollada, M. Iglesias, P. J. Sanz Miguel, Inorganic Chemistry, 2014, 53, 10654-10659, doi: 10.1021/ic501715h.

[39] G. Roymahapatra, S. M. Mandal, W. F. Porto, T. Samanta, S. Giri, J. Dinda, O. L. Franco, P. K. Chattaraj, Current Medicinal Chemistry, 2012, 19, 4184-4193, doi: 10.2174/092986712802430090.

[40] K. R. Justin Thomas, J. T. Lin, Y. T. Tao, C. W. Ko, Journal of the American Chemical Society, 2001, 123, 9404-9411, doi: $10.1021 / \mathrm{ja0} 0819 \mathrm{~s}$.

[41] J. Huang, Y. Niu, W. Yang, Y. Mo, M. Yuan, Y. Cao, Macromolecules, 2002, 35, 6080-6082, doi: 10.1021/ma0255130. [42] K. Öfele, E. Tosh, C. Taubmann, W. A. Herrmann, Chemical Reviews, 2009, 109, 3408-3444, doi: 10.1021/cr800516g.

[43] V. J. Catalano, L. B. Munro, C. E. Strasser, A. F. Samin, Inorganic Chemistry, 2011, 50, 8465-8476, doi: 10.1021/ic201053t.

[44] V. J. Catalano, A. O. Etogo, Inorganic Chemistry, 2007, 46, 5608-5615, doi: 10.1021/ic070260i.

[45] T. Lu, J. Y. Wang, L. X. Shi, Z. N. Chen, X. T. Chen, Z. L. Xue, Dalton Transactions, 2018, 47, 6742-6753, doi: $10.1039 / \mathrm{c} 8 \mathrm{dt} 00599 \mathrm{k}$.

[46] T. Samanta, B. Kumar Rana, G. Roymahapatra, S. Giri, P. Mitra, R. Pallepogu, P. Kumar Chattaraj, J. Dinda, Inorganica Chimica Acta, 2011, 375, 271-279, doi: 10.1016/j.ica.2011.05.017.

[47] F. Sanda, T. Nakai, N. Kobayashi, T. Masuda, Macromolecules, 2004, 37, 2703-2708, doi: 10.1021/ma035972g. 
[48] J. Dinda, A. Nandy, B. K. Rana, V. Bertolasi, K. Das Saha, C. W. Bielawski, RSC Advances, 2014, 4, 60776-60784, doi: 10.1039/c4ra09591j.

[49] V. Rani, H. B. Singh, R. J. Butcher, Organometallics, 2017, 36, 4741-4752, doi: 10.1021/acs.organomet.7b00620.

[50] M. J. Frisch, G. W. Trucks, H. B. Schlegel, Inc., Wallingford CT, 2013.

[51] M. K. Dash, S. Das, S. Giri, G. Chandra De, G. Roymahapatra, Journal of the Indian Chemical Society, 2021, 98, 100134, doi: 10.1016/j.jics.2021.100134.

[52] T. Chowdhury, J. Dutta, G. Roymahapatra, S. M. Mandal, Journal of the Indian Chemical Society, 2020, 97, 1279-1285, doi: 10.5281/zenodo.5656715.

[53] S. Sinha, S. Das, G. Roymahapatra, S. Giri, International Journal of HIT Transaction on ECCN, 2020, 6, 7-13, https://hithaldia.in/eccn/.

[54] R. Parida, G. N. Reddy, A. Khanna, G. Roymahapatra, S. Giri, International Journal of HIT Transaction on ECCN, 2018, 4, 1-7, https://hithaldia.co.in/eccn/.

[55] R. Parida, M. K. Dash, S. Giri, G. Roymahapatra, Journal of the Indian Chemical Society, 2021, 98, 100065, doi: 10.1016/j.jics.2021.100065.

[56] N. M. O'Boyle, A. L. Tenderholt, K. M. Langner, Journal of Computational Chemistry, 2008, 29, 839-845, doi: 10.1002/jcc. 20823 .

[57] https://www.originlab.com/origin.

[58] J. J. McKinnon, D. Jayatilaka, M. A. Spackman, Chemical Communications, 2007, 3814-3816, doi: 10.1039/b704980c.

[59] M. A. Spackman, J. J. McKinnon, D. Jayatilaka, CrystEngComm, 2008, 10, 377-388, doi: 10.1039/b715227b.

[60] J. J. McKinnon, M. A. Spackman, A. S. Mitchell, Acta Crystallographica Section B Structural Science, 2004, 60, 627668, doi: 10.1107/s0108768104020300.

[61] A. Parkin, G. Barr, W. Dong, C. J. Gilmore, D. Jayatilaka, J. J. McKinnon, M. A. Spackman, C. C. Wilson, CrystEngComm, 2007, 9, 648, doi: 10.1039/b704177b.

[62] M. A. Spackman, D. Jayatilaka, CrystEngComm, 2009, 11, 19-32, doi: 10.1039/b818330a.

[63] M. H. Reineke, T. M. Porter, A. L. Ostericher, C. P. Kubiak, Organometallics, 2018, 37, 448-453, doi: 10.1021/acs.organomet.7b00847.

[64] W. Ghattas, H. Müller-Bunz, M. Albrecht, Organometallics, 2010, 29, 6782-6789, doi: 10.1021/om100925j.

[65] J. L. Díaz, A. Dobarro, B. Villacampa, D. Velasco, Chemistry of Materials, 2001, 13, 2528-2536, doi: 10.1021/cm001218n.

[66] R. M. Adhikari, R. Mondal, B. K. Shah, D. C. Neckers, The Journal of Organic Chemistry, 2007, 72, 4727-4732, doi: 10.1021/jo0703911.

[67] A. Bondi, The Journal of Physical Chemistry, 1964, 68, 441451, doi: 10.1021/j100785a001.

[68] M. C. Etter, J. C. MacDonald, J. Bernstein, Acta Crystallographica Section B Structural Science, 1990, 46, 256262, doi: 10.1107/s0108768189012929.

[69] B. K. Rana, J. Dinda, H. S. Das, M. H. Cardoso, O. L. Franco, P. P. Bag, P. K. Mahapatra, S. Giri, G. Roymahapatra, Journal of the Indian Chemical Society, 2020, 97, 2699-2712, doi: 10.5281/zenodo.5751265.

[70] M. Häussler, J. Liu, R. Zheng, J. W. Y. Lam, A. Qin, B. Z. Tang, Macromolecules, 2007, 40, 1914-1925, doi: $10.1021 / \mathrm{ma} 0623461$.

[71] B. K. Rana, G. Roymahapatra, H. S. Das, S. Giri, M. H. Cardoso, O. L. Franco, N. K. Kiran, M. K. Santra, P. P. Bag, V. Bertolasi, J. Dinda, Journal of Molecular Structure, 2021, 1231, 129822, doi: 10.1016/j.molstruc.2020.129822.

[72] G. Roymahapatraa, D. Sarkar, A. Nandi, S. Giri, T. K. Mondal, A. Mahapatra, W-S. Hwang, J. Dinda, Journal of the Indian Chemical Society, 2015, 92, 79-88, doi: 10.5281/zenodo.5602988.

[73] K. Kajiwara, S. Pradhan, T. Haraguchi, C. Sinha, R. Parida, S. Giri, G. Roymahaptra, T. Akitsu, Symmetry, 2020, 12, 797, doi: 10.3390/sym 12050797.

[74] G. N. Reddy, A. Mukhopadhyay, R. Parida, G. Roymahapatra, S. Giri, Journal of the Indian Chemical Society, 2018, 95, 951-959, doi: 10.5281/zenodo.5642793.

[75] R. Parida, G. N. Reddy, A. Ganguly, G. Roymahapatra, A. Chakraborty, S. Giri, Chemical Communications, 2018, 54, 39033906, doi: 10.1039/c8cc01170b.

[76] R. Parida, S. Das, L. J. Karas, J. I. C. Wu, G. Roymahapatra, S. Giri, Inorganic Chemistry Frontiers, 2019, 6, 3336-3344, doi: 10.1039/c9qi00873j.

[77] K. Kajiwara, S. Yamane, T. Haraguchi, S. Pradhan, C. Sinha, R. Parida, S. Giri, G. Roymahaptra, D. Moon, T. Akitsu, Journal of Chemistry and Chemical Engineering, 2019, 13, 23-33, doi: 10.17265/1934-7375/2019.01.003.

[78] R. Parida, M. Rath, S. Sinha, G. Roymahapatra, S. Giri, Journal of the Indian Chemical Society, 2020, 97, 2689-2697, doi: 10.5281/zenodo.5656084.

[79] H. Sato, I. Beppu, T. Haraguchi, T. Akitsu, R. Parida, S. Giri, G. Roymahapatra, I. H. Joe, Journal of the Indian Chemical Society, 2018, 95, 1487-1495, doi: 10.5281/zenodo.5644576.

[80] G. Roymahapatra, J. Dinda, A. Mishra, A. Mahapatra, W. S. Hwang, S. M. Mandal, Journal of cancer research and therapeutics, 2015, 11, 105-113, doi: 10.4103/0973-1482.150416. [81] L. Boubakri, A. Chakchouk-Mtibaa, A. S. Al-Ayed, L. Mansour, N. Abutaha, A. H. Harrath, L. Mellouli, I. Özdemir, S. Yasar, N. Hamdi, RSC Advances, 2019, 9, 34406-34420, doi: 10.1039/c9ra05605j.

[82] G. Balamurugan, R. Ramesh, J. G. Malecki, ChemistrySelect, 2017, 2, 10603-10608, doi: 10.1002/slct.201702102.

[83] W. Li, T. Wagener, L. Hellmann, C. G. Daniliuc, C. MückLichtenfeld, J. Neugebauer, F. Glorius, Journal of the American Chemical Society, 2020, 142, 7100-7107, doi: 10.1021/jacs.0c00985.

[84] W. Li, M. P. Wollenburg, F. Glorius, Journal of the American Chemical Society, 2017, 139, 2585-2588, doi: 10.1021/jacs.6b13124. 


\section{Author information}

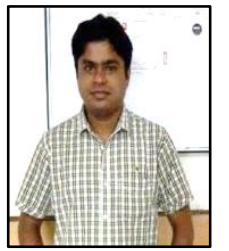

Dr. Bidyut Kumar Rana, Chemist of Quality Control Laboratory at Indian Oil Corporation Limited, Haldia Refinery, Haldia 721606, West Bengal, India. He got his Ph.D degree from Jadavpur University, Kolkata in the year 2017 on the field of annulated and non-annulated $N$ Heterocyclic Carbene Chemistry, Synthesis, Structures, Catalysis and Biological applications. Dr. Rana has graduated from Mahishadal Raj College under Vidyasagar University 2006 and master in Organic Chemistry in the year 2008 from the same university. He has qualified NET CSIR (2008 and 2009) and GATE (2008). He has also done chemical engineering (IIChem) from Jadavpur University. He has published his research articles in national and international journals of repute. For his contribution in research, he has been awarded as the 'Life Fellow of Indian Chemical Society' (FICS), India, in 2020. The areas of special interest in his research include Annulated and Non-annulated $\mathrm{N}$ Heterocyclic Carbene (NHC) complexes using various main group and transitional metals, their synthesis, catalysis, anticancer activity, spectral study and computational interpretation.

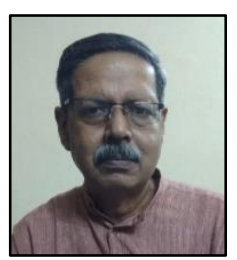

Dr. Pradip Kumar Mahapatra, Associate Professor, Department of Chemistry, Jadavpur University, Kolkata - 700 032, West Bengal, India, graduated from Presidency College, Kolkata (Calcutta University) in 1983 with Honours in Chemistry and completed his M. Sc. degree in Chemistry with Physical Chemistry special from Rajabazar Science College, Calcutta University in 1986. After completion of his Ph.D degree from Jadavpur University, Kolkata in the year 1993, he worked as postdoctoral fellow in Bose Institute, Kolkata between 1994 and 2000 in the field of bio-physical chemistry; Drug-protein interactions; Synthesis and modification of small peptides and their characterization. Before joining as lecturer in chemistry at Jadavpur University in 2002, he served Dinabandhu Mahavidyalaya, Bongaon, North 24Parganas, WB from 2001 to 2002 as lecturer in chemistry. He is a life member of Indian Society for Surface Science and Technology, JU, Kolkata. Since 2015, he is the elected General Secretary of Paschimbanga Vigyan Mancha (PBVM), the largest people's science organization of India, engaged in propagating scientific temper, environmental awareness and advocacy for self-reliance in the field of science and technology of our country. His areas of special interest in research include
Biophysical Chemistry; Drug-protein interactions; Synthesis and modification of small peptides and their characterization; nano-materials; Photo-physical studies of N-heterocyclic carbene complexes.

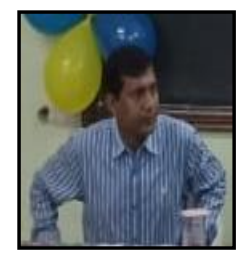

Joydev Dinda is presently serving as Associate Professor \& HOD, P.G. Department of Chemistry, Utkal University, Bhubaneswar. He is graduated from Bajkul Milani Mahavidyalaya in 1996 and completed his M.Sc. (Chemistry) from Vidyasagar University in 1998. In 2003 he is awarded Ph.D. from Burdwan University under supervision of Prof. Chittaranjan Sinha. He did his Postdoctoral work in National Dong -Hwa University, Taiwan (2004-05), Heidelberg University, Germany (2005-06) and Universite of Joseph Fourier, France (2008-09). He also received internal fellowship from Ministry of Education and Culture, Spain in 2006. He has served School of Engineering Science, Haldia Institute of Technology, Haldia more than 6 years and initiated Department of Chemistry and Chaired HOD in ITM University, Gwalior. He has published more than 50 internationals journals of repute and supervised five Ph.D. scholars. Most significant achievements of Dr. Dinda's group are the easy and straight forward synthesis of $\mathrm{Au}(I I I)-N$ heterocyclic carbenes from gold(I)-N-heterocyclic carbenes following disproportionation pathway. Dr. Dinda is a 'Life Fellow of Indian Chemical Society' (FICS).

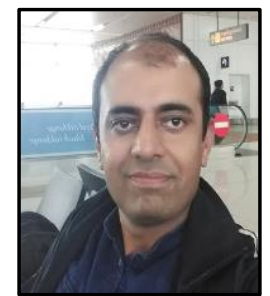

Dr. Deepak Chopra is currently Professor in the Department of Chemistryat Indian Institute of Science Education and Research (IISER) Bhopal, Madhya Pradesh since March 2009. He received his degree in B.Sc. (H) Chemistry (Gold Medallist) from Jadavpur University in 2001. Following which he pursued the Integrated PhD program (which includes a 3 year M.S. program) from Indian Institute of Science, Bangalore in Chemical Crystallography. He continued as a postdoctoral fellow in IISc till 2007. He further continued his postdoctoral work at the University of Toledo, Ohio, USA in the field of electron density analysis in molecular crystals. His active research interests, includes investigation of polymorphism in drugs and pharmaceuticals, computational analysis of non-covalent interactions, in situ crystallization, experimental/theoretical electron density analysis and mechanical/electrical properties in molecular crystals. He is currently on the Editorial Board of Journal of Molecular Structure, Elsevier, Editoral Advisory Board of the journal CrystEngComm, RSC, a Co-Editor of the journal Acta 
Crystallographica E (IUCr, Chester), a 'Life Fellow of the Indian Chemical Society' (FICS) and a 'Fellow of the Royal Society of Chemistry' (FRSC).

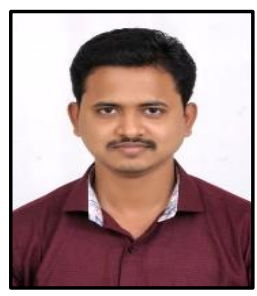

Dr. Keshab Bairagi currently working as Adhoc faculty in Shree Mathuradas Mohota Science College Nagpur. He started his research carrier with Dr. Susanta K. Nayak in the Department of Chemistry Visvesvaraya National Institute of Technology Nagpur also he got PhD degree in June 2021 from same institute. His research interests are mainly focused on the synthesis and design of halogen and hydrogen bonded pharmaceutical active molecules, pharmaceutical co-crystals, liquid crystals systems etc. In his early research carrier, he published 14 research paper. He got MSc degree in 2013 from government institute of science Nagpur with third merit rank in university. He has also National level exam i.e. Graduate Aptitude Test for Engineering (GATE-2015) and State Eligibility Test (SET-2016) for assistant professorship. He is also member of Indian Crystallographic Association (ICA) and life time member of Indian Liquid Crystal Society.

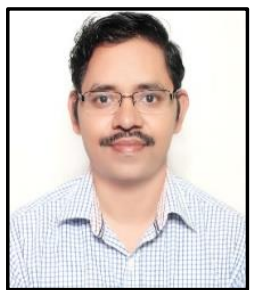

Dr. Susanta K. Nayak is currently Assistant Professor in Department of Chemistry, Visvesvaraya National Institute of Technology (VNIT), Nagpur, Maharashtra since January 2015. After completion of his MSc (Chemistry) degree from Utkal University, Odisha in 2003, he obtained his PhD degree from Indian Institute of Science (IISc), Bangalore in 2010 on structural chemistry. He worked as a Research Associate at the same institute for a period few months before moving to Centre for Nano Science \& Technology@Polimi, Istituto Italiano di Tecnologia (IIT) \& NFMLab-DCMIC "Giulio Natta" Politecnico di Milano, Italy to pursue his postdoctoral work on 'In situ cryocrystallography study of nanostructured materials for opto-electronic applications', till September 2012. He was awarded with Marie Curie Research Fellow (IIF) to work at Université de Rennes 1, France on 'Luminescent hybrid nanomaterial showing liquid crystalline properties study' during Oct 2012-Sept 2014. His research group at VNIT is mainly emphasizing on Organic based molecules utilizing Crystal Engineering, Supramolecular chemistry, liquid crystals for biological activity study as well as material application along with the establishment of Structure-Property relationship through experimental and theoretical study.

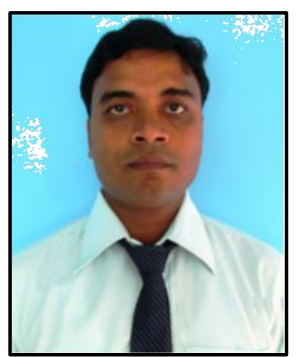

Dr. Himadri Sekhar Das was presently working as post doc fellow. He got his $\mathrm{Ph}$. $D$ degree from Indian Institute of Engineering Science and Technology (IIEST), Shibpur in 2021, M. Tech from Maulana Abul Kalam Azad University of Technology, West Bengal in 2010. His research area was Doped $\mathrm{ZnO}$ based thin Film for different optoelectronics applications. Synthesis and characterization of organic-inorganic Perovskite material for Solar cell. ZnO based transparent conducting oxide thin film for mesoporous TiO2 based dye sensitized solar cell. Solid state electrolytebased dye sensitized solar cell: stability and device performance. Solvo thermal synthesis of $\mathrm{ZnO}$ nanoparticle. Polymer based Organic Solar Cell, Photonic Materials and devices (LED \& Thin Film Display). He has been published more than 20 research paper. Dr. Das is a 'Life Fellow of the Indian Chemical Society' (FICS).

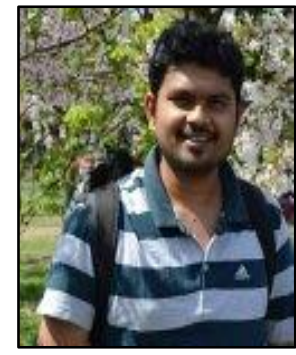

Dr. Santanab Giri is currently working as an assistant professor in the School of Applied Science and Humanities, Haldia Institute of Technology. He received his BSc (Chemistry Honors) and MSc (Chemistry) degrees from Vidyasagar University, West Bengal. Then he joined the research group of Professor $P$. K. Chattaraj for his PhD degree in the Department of Chemistry, Indian Institute of Technology, Kharagpur as an Institute Fellow. In 2011, he moved to Pontificia Universidad Catolica de Chile for his postdoctoral study with Professor Alejandro Toro-Labbe. After finishing his first postdoctoral tenure, he moved to Virginia Commonwealth University in 2013 to work with Professor Puru Jena. Dr. Giri returned to India as a DST Inspire Faculty. He worked in this position in NIT Warangal and NIT Rourkela from 2014-2018. For the last 10 years, he is actively involved in designing metal clusters, molecules with unusual properties using density functional theory and abinitio molecular dynamics techniques. He has more than 120 journals of International repiute and 08 book chapters. He has successfully carried out several projects funded by Govt. of India. He is also a recipient of two national awards (Professor Santi Ranjan Palit award and Sir P. C. Ray award) and one international award (Eli-Lilly Asia Outstanding Thesis Award) and prestigious 'Bharat Gaurabh Award - 2018' from IISF, India. Dr. Giri is a 'Life Fellow of the Indian Chemical Society' (FICS). 


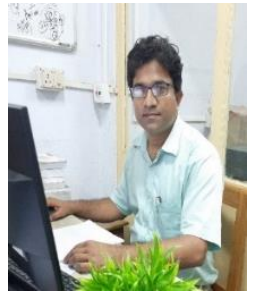

Dr. Gourisankar Roymahapatra, currently working as the Associate Professor of Chemistry at the School of Applied Science and Humanities in Haldia Institute of Technology (HIT), Haldia 721657, West Bengal, India, is a passionate researcher of chemistry. He completed his Ph.D from Jadavpur University, Kolkata in the year 2014 with N-Heterocyclic Carbene Chemistry as a major field under the guidance of Dr. Joydev Dinda and Prof. Ambikesh Mahapatra. Dr. Roymahapatra graduated (B.Sc with Chemistry Honors) from Midnapore College under Vidyasagar University (2000) and master in Physical Chemistry (2003), in Organic Chemistry (2005), from DAV PG College at Kanpur under CSJM University, India. Before coming to academia, he worked at MCC PTA Chem. Corp. Pvt. Ltd India (MCPI), Haldia, (2003 2011) as a Senior Chemist. He joined Global Institute of Science and Technology, Haldia, India, as Lecturer in Chemistry in the year 2011 and then he moved to Haldia Institute of Technology in 2015 as an Assistant Professor of Chemistry. His areas of special interest in research include $\mathrm{N}$-Heterocyclic Carbene (NHC) complexes, organometallics, catalysis, antibiotics, anti-carcinogenic and gas adsorption, super alkali and computational chemistry. His current research interest is on designing and developing new molecules and materials for Hydrogen storage, and also to develop thin film semiconductors and super alkali materials for industrial applications. For his contribution in research, he got 'Distinguished Young Scientist Award in Chemistry -2014' from 'World Science Congress', India, prestigious 'Bharat Gaurabh Award - 2018'from IISF, India, and Indian Chemical Society Research Excellence Award 2021, from Indian Chemical Society, India. Dr. Roymahapatra is a life Fellow of Indian Chemical Society (FICS), and life Fellow of Institutes of Chemistry (India) (FIC). He is the elected Vice-president of Haldia Vigyan Parishad (HVP) from 2018-2020, and 20212023. Dr. Roymahaptra is the editor of 'Education in Chemical Science and Technology', and 'Chemical Warta' published by Indian Chemical Society, and is the editorial board member and reviewer of several national and international journals.

Publisher's Note: Engineered Science Publisher remains neutral with regard to jurisdictional claims in published maps and institutional affiliations. 